\title{
Effects of Processing Methods on the Nutritional and Anti-Nutritional Properties of Soybeans (Glycine max)
}

\author{
${ }^{1}$ Pele, G.I.; ${ }^{2}$ Ogunsua, A.O. ${ }^{3}$ Adepeju, A.B.; ${ }^{4}$ Esan, Y.O.; and ${ }^{5}$ Oladiti, E.O. \\ ${ }^{1,2,3,4}$ Department of Food Science and Technology, Joseph Ayo Babalola University, Ikeji-Arakeji, P.M.B. 5006, Ilesa, \\ Osun State, Nigeria. \\ ${ }^{1,4,5}$ Department of Food Science and Technology, Federal University of Technology, P.M.B. 704, Akure, Ondo State, \\ Nigeria. \\ ${ }^{1}$ Corresponding Author Email: ife_pele@ymail.com, +2348034899527
}

\begin{abstract}
Soybean is a leguminous vegetable that grows in tropical, subtropical, and temperate climates and it is a principal vegetable protein source in animal feed industry in Nigeria. The study investigated the effects of traditional processing methods on the nutritional and anti-nutritional properties of soybean. Soybeans were subjected to different processing methods which were sun drying and milling which serves as the control (sample A); soaking for $24 \mathrm{~h}$, sun drying and milling (sample B); soaking for $12 \mathrm{~h}$, de-hulling, sun drying and milling (sample C) and sprouting for 120h, sun drying and milling (sample D). Results from the proximate composition of soybean showed that protein content of the samples were in the range from $\mathbf{2 3 . 9 8}$ to $\mathbf{2 8 . 4 4 \%}$ with a significant increase in sample $B, C$ and $D$. The fat content ranged from 20.51 to $26.20 \%$, while crude fibre ranged from 4.68 to $6.58 \%$. The moisture content which ranged from 7.23 to $10.92 \%$ showed a significant decrease in the control. The anti-nutritional properties of the samples showed that phytic acid was in the range of 5.45 to $8.05 \%$ which significantly decrease in sample $B, C$ and $D$. The tannin content ranged from 19.23 to $25.23 \mathrm{mg} / 100 \mathrm{~g}$ while the protease inhibitor ranged from 4.91 to $7.09 \%$ with a significant decrease in sample $B, C$ and $D$. The study showed that tradition processing methods can significantly increase the nutritional properties of soybeans while it can also significantly reduce the anti-nutritional properties of soybeans thereby increasing the bioavailability of its nutrients.
\end{abstract}

Key words: de-hulling, glycine max, milling, proximate, sprouting, sun drying

\section{INTRODUCTION}

Legumes are important sources of protein, carbohydrates, dietary fiber and minerals. Only a few of the known legume species are extensively promoted and used. The soybean (US) or soya bean (UK) (Glycine $\max$ ) is specie of legume native to East Asia, widely grown for its edible bean which has numerous uses. The plant is classed as an oilseed rather than a pulse by the UN Food and Agricultural Organization (FAO, 2008). Soybean can be used as a sole source of protein in poultry and swine diets. Fabiyi and Hamidu (2011) reported that the quality of protein of soybean can be comparable to that of animal protein sources such as meat and milk; it is limiting in sulphur containing amino acids such as methionine and cysteic but contain sufficient lysine to overcome the lysine deficiency of cereal (Potter and Hotchkiss, 1995). Increasing the nutritional quality of soybean and other legumes can be accomplished by several processing methods such as toasting, cooking, extruding, salt treatment, fermentation, germination pressure cooking, cooking, soaking, urea treatment (Akande and Fabiyi, 2010).

Soybean contains approximately $40-45 \%$ protein and $18-22 \%$ oil (Goyal et al., 2012) and is a rich source of vitamins and minerals. Raw soybean contains a number 
of anti-nutritional factors such as trypsin inhibitors, phytic acid and saponins. which decrease nutritive value of grain legumes and cause health problems to both human and the animals when taken in large amounts (Mikic et al., 2009; Sharma et al., 2011). Trypsin inhibitors can block either trypsin or chymotrypsin, reduce the hydrolysis of dietary protein, decrease amino acid absorption and thereby reduce digestibility (Roy et al., 2010). These anti-nutrients should be removed to improve the nutritional quality and organoleptic acceptability of legumes so that they can be effectively used as potential human food; processing methods can also enhance the nutritional value of soybean by increasing the bioavailability of amino acid, vitamins and also protein digestibility (Prodanov et al., 2004). Okagbare and Akpodiete (2006) also reported that methods of processing the seeds to eliminate antinutritional factors have been a major challenge to most farmers. It is against this background that this research work attempt to evaluate processing methods of soybean seeds on the nutritional and anti-nutritional properties of soybeans.

\section{MATERIALS AND METHODS}

\section{Source of Materials}

Soybeans (Glycine max) were obtained from a local market in Ado-Ekiti, Nigeria. The beans were sorted and cleaned from extraneous materials.

\section{Chemicals and Reagents}

Mercuric oxide, reagent grade, Potassium sulphate or anhydrous sodium sulphate, reagent grade, Sulphuric acid $(98 \%)$, nitrogen free, Paraffin wax, $40 \%$ solution of sodium hydroxide; $4 \%$ sodium sulphate solution, Boric acid indicator solution, methyl red and $0.2 \%$ bromocresyl were products of Eagle Scientific Limited, England while Petroleum ether, Antifoam (e.g. octyl alcohol or silicone), Ethyl alcohol at $95 \%(\mathrm{v} / \mathrm{v})$ were products of B.D.H. Limited, England. All other reagents used were of analytical grade.

\section{Production of Soybeans Flour}

Soybeans were sorted, washed and four different processing methods were employed to produce soybeans flour. Sample A which serves as control, soybeans sundried and milled into flour while sample B, soybeans soaked in water at 12 C for $24 \mathrm{~h}$, sundried and milled into flour. Sample C, soybeans soaked for $12 \mathrm{~h}$, dehulled, sundried and milled into flour while sample $D$, soybeans sprouted for $120 \mathrm{~h}$, dried and milled into flour.
Sprouting of soybeans was done by soaking the seeds in water for $24 \mathrm{~h}$. The seeds were removed and germinated by spreading the seeds on the jute bags and covered with the same material. Water was sprinkled on the jute bags twice daily until the seeds began to sprout. The sprouted seeds were sundried for 4 days and milled into flour.

\section{Determination of Proximate Composition}

Analysis of moisture content, crude protein, crude fat, ash and fibre were determined by method described by AOAC (2005). Total carbohydrate content was determined by subtracting the crude protein, fat, ash and crude fibre percentages from $100 \%$.

\section{Determination of Anti-nutritional Properties}

Gravimetric determination of tannin was done according to the method of Makkar and Goodchild (1996), while phytate was determined according to the method of Young and Greaves (1990). The determination of protease inhibitor was done according to method of Ladd and Butler (1972).

\section{Statistical Analysis}

Data obtained from the experiment were subjected to statistical analysis using SPSS version 20, while the statistical analysis showed significant differences, the means were separated using the Duncan Multiple Range Test (DMRT).

\section{RESULTS AND DISCUSSION}

\section{Effect of Traditional Processing Methods on the Proximate Composition of Soybeans}

The results of the effect of traditional processing methods on the proximate composition of soybeans are presented in Table1. The crude protein (\%) content of the control (sample A), sample B , C and D were 23.98, 24.67, 25.07 and 28.44 respectively. The results showed that there is significant increase in the protein content of sample $D$ as compared with the other samples, with sample A having the lowest protein content. The increase in the protein content of sample $D$ could be due to sprouting which increased the bioavailability of the crude protein in the soybeans. The high increase in crude protein of sprouted soybean could be attributed to complex biochemical changes that occur during hydration and sprouting, which lead the protein constituent being broken down by enzymes into simple compounds that are 
Pele et al. 011

Table 1. Proximate Composition of Processed Soybeans Samples (\%)

\begin{tabular}{lccll}
\hline Parameters/ Samples & \multicolumn{1}{c}{$\mathbf{A}$} & \multicolumn{1}{c}{ B } & C & D \\
\hline Moisture content & $7.23^{\mathrm{c}} \pm 0.27$ & $8.43^{\mathrm{bc}} \pm 0.07$ & $9.14^{\mathrm{b}} \pm 0.63$ & $10.92^{\mathrm{a}} \pm 0.29$ \\
Ash content & $4.76^{\mathrm{c}} \pm 0.90$ & $5.27^{\mathrm{b}} \pm 0.68$ & $3.83^{\mathrm{d}} \pm 0.39$ & $6.75^{\mathrm{a}} \pm 0.60$ \\
Crude fiber & $6.58^{\mathrm{a}} \pm 0.38$ & $5.10^{\mathrm{b}} \pm 0.30$ & $5.15^{\mathrm{b}} \pm 0.17 \mathrm{a}$ & $4.68^{\mathrm{c}} \pm 0.78$ \\
Fat content & $26.20^{\mathrm{a}} \pm 0.75$ & $23.35^{\mathrm{b}} \pm 0.83$ & $22.43^{\mathrm{b}} \pm 0.90$ & $20.51^{\mathrm{a}} \pm 0.69$ \\
Crude protein & $23.98^{\mathrm{c}} \pm 0.97$ & $24.67^{\mathrm{b}} \pm 0.10$ & $25.07^{\mathrm{b}} \pm 0.63$ & $28.44^{\mathrm{a}} \pm 2.50$ \\
Carbohydrate & $38.48^{\mathrm{c}} \pm 0.68$ & $41.61^{\mathrm{b}} \pm 0.35$ & $43.52^{\mathrm{a}} \pm 0.50 \mathrm{~b}$ & $39.62^{\mathrm{c}} \pm 0.71$ \\
\hline
\end{tabular}

used to make new compounds. The increase in hydrolytic activities of the enzymes of sprouting resulted in improvement in the constituent of total crude protein due to disappearance of starch (Ramadan, 2012), while the increase in crude protein content with respect to sprouting is especially important from the nutritional point of view as it would increase digestibility and absorption. The result however showed that there is no significant difference in the amount of protein in sample B and C, though soaking and de-hulling significantly increase the amount of protein content when comparing with sample A. The crude fat (\%) of sample A, B, C and D were 26.20 , $23.35,22.43$, and 20.51 respectively. The results showed that crude fat significantly decreased in sample $D$, while there is a significant increase in sample $A$, this could be due to biochemical reaction and dissociation of lipid complexes as reported by Ragab et al. (2010), the implication of this however is that sample $A$ will be more prone to rancidity than the other samples.

\section{Values are means of triplicates}

Values along the same row followed by different superscripts are significantly different $(p \leq 0.05)$.

Where: Sample A: Control, soybeans dried and milled milled into flour

Sample B: Soybeans soaked for $24 \mathrm{~h}$, dried and

Sample C: Soybeans soaked for $12 \mathrm{~h}$, de-hulled, dried and milled into flour

Sample D: Soybeans sprouted for $120 \mathrm{~h}$, dried and milled into flour.

The moisture content (\%) of sample A, B, C and D were $7.91,8.43,9.14$ and 10.92 respectively. Results showed that there is significant increase in the moisture content in sample $D$, while the moisture content significantly decrease in sample $A$ though there is no significant difference in sample $A$ and $B$; there is also no significant difference between sample $B$ and $C$. The results agreed with the results obtained by Ramadan (2012) who reported that raw soybeans (Giza 21 and Giza 35) had moisture content of 6.15 and 7.32 respectively. The effect of this result is that sample D would be more prone to microbial spoilage compared with other samples. The ash (\%) content of sample A, B, C and D were $3.83,4.76$, 5.27 and 6.75 respectively. Results showed that there is significant difference in all samples. There is significant increase in the ash content of sample D while sample $C$ is significantly low; the increase in the ash content of sample D can be observed as the significant effect of sprouting on the bioavailability of the minerals content of soybeans while the significant decrease recorded in sample B could be due to de-hulling, where most of the pericarp that comprise the ash can be found to have been de-hulled. This is however in consonance with Ramadan, 2012, who reported that soybeans (Giza 21 and Giza 35) had ash content of 5.80 and 6.80 respectively. The carbohydrate (\%) content of sample A, $B, C$ and $D$ were $38.48,41.61,43.52$, and 39.62. The results showed significant difference, while sample $C$ significantly increased in carbohydrate, sample $A$ is significantly low though there is no significant difference between sample $A$ and $D$.

\section{Effects of Traditional Processing Methods on the Anti-nutritional Properties of Soybeans Flour.}

The results of the effects of traditional processing methods on the anti-nutritional properties of soybeans are presented in Table 2. The phytic acid (\%) of sample A, B, C and D were 8.05, 6.27, 5.58 and 5.45 respectively. Results showed that there is a significant difference in the entire samples. The phytic acid of sample $D$ significantly decreased though there is also a significant decrease in sample $B$ and $C$ while phytic acid is high in sample A. The reduction effect of phytic acid in soybeans could be due to leaching, de-hulling and sprouting. The phytic acid reported in this study is lower than those reported by Odumodu (2010) in fermented soybean. Mikic et al. (2009) reported that phytic acid content in soybean seeds and products was about 1$1.5 \%$ of dry matter. Osman (2007) also reported reduction in phytic acid content in different processing methods (soaking, cooking and germination).

\section{Values are means of triplicates}

Values along the same row followed by different superscripts are significantly different $(p \leq 0.05)$ 
012 Afr. J. Food Sci. Technol.

Table 2. Anti-nutritional Properties of Processed Soybeans Samples

\begin{tabular}{lclcc}
\hline Parameter & A & B & C & D \\
\hline Phytic Acid (\%) & $8.05^{\mathrm{a}} \pm 0.87$ & $6.27^{\mathrm{b}} \pm 0.48$ & $5.58^{\mathrm{c}} \pm 0.32$ & $5.45^{\mathrm{d}} \pm 0.72$ \\
Tannin (mg/100g) & $25.23^{\mathrm{a}} \pm 0.28$ & $21.55^{\mathrm{b}} \pm 0.97$ & $19.23^{\mathrm{c}} \pm 0.20$ & $20.13^{\mathrm{c}} \pm 0.18$ \\
Protease inhibitor (\%) & $7.09^{\mathrm{a}} \pm 0.81$ & $6.03^{\mathrm{b}} \pm 0.26$ & $5.72^{\mathrm{c}} \pm 0.30$ & $4.91^{\mathrm{d}} \pm 0.39$ \\
\hline
\end{tabular}

The tannin content $(\mathrm{mg} / 100 \mathrm{~g})$ of sample A, B, C and D were $25.23,21.55,19.23$ and 20.13 respectively. Results showed that there was significant difference in the tannin content of the samples Tannin content was significantly decreased in sample B, C and D. This could be attributed as a significant effect of soaking, de-hulling and sprouting which significantly decreased the effect on tannin. Results also indicated that there is no significant difference between sample $C$ and $D$ in term of tannin content which showed the significant reduction effect by de-hulling and sprouting of soybeans. The protease inhibitor of sample A, B, C and D were 7.09, 6.03, 5.72 and $4.91 \%$ respectively. The results showed a significant difference in the entire samples. The protease inhibitor of sample $B, C$ and $D$ is significantly decreased; this could be due to soaking, de-hulling and sprouting which are of significant in its reduction.

\section{CONCLUSION}

The research has revealed the effect of traditional processing methods on the nutritional and anti-nutritional properties of soybeans. The results obtained have shown that traditional processing significantly improved the nutritional quality of soybeans and reduced the antinutritional properties of soybeans. Protein content of soybeans was significantly increased while the fat content significantly reduced due to soaking, de-hulling and sprouting. The phytic acid which hinders minerals absorption was also significantly reduced due to sprouting. Fat content of soybeans which could have a negative effect on rancidity was significantly reduced due to soaking, de.-hulling and sprouting.

\section{REFERENCES}

Akande KE, Fabiyi EF( 2010). Effect of processing methods on some anti-nutritional factors in legume seeds for poultry feeding. International Journal of Poultry Science 9: 996-1001.

AOAC (2005). Official Methods of Analysis of the Association of Official Analytical Chemists. AOAC, Washington, D.C.

Fabiyi EF, Hamidu BM (2011). Adoption of improved technologies in soybean processing utilization in Tafawa Balewa Local Government
Area of Bauchi State, Nigeria. Afr. J. Food Agri. Nutr. Dev., 11: $4527-4537$

FAO (2008). State of food and agriculture. Rome, Italy: Food and Agriculture Organization in Developing Countries.

Goyal R, Sharma S, Gill BS(2012). Variability in the nutrients, antinutrients and other bioactive compounds in soybean [Glycine $\max$ (L.) Merrill] genotypes. Journal of Food Legumes 25: 314-320.

Ladd JN, Butler JH(1972). Short term assay on soil proteolytic enzyme activity using proteins and dipeptide substrate. Soil biology and biochemistry. 4: 19-39

Makkar AOS, Goodchild AV(1996). Quantification of Tannin: A laboratory Manual International Centre for Agricultural Research in Dry Areas (ICARDA). Aleppo, Syria. IV p 25

Mikic A, Peric V, Dordevic V, Srebric M, Mihailovic V(2009). Antinutritional factors in some grain legumes. Biotechnology in Animal Husbandry 25(5-6): 1181-1188.

Odumodu CU(2010). Nutrient and antinutrients content of dehulled and soybean. Continental J. Food Sci., 4: 38-45.

Okagbare GO, Akpodiete $\mathrm{OJ}(2006)$. Soybean in pre ruminant nutrition: A review. Nig. J. Anim. Prod., 33: 83-86.

Osman MA(2007). Effect of different processing methods on nutrient composition, antinutritional factors and in vitro protein digestibility of Dolichos lablab bean (Lablab purpureus (L.) sweet). Pakistan Journal of Nutrition 6: 299-303.

Potter WN, Hotchkiss JH(1995). Food sciences: 5th Edition. Chapman and Hall book International. Thompson Publishing, Pp: 28-30.

Prodanov M, Vierra I, Vidal-Valverde $\mathrm{CH}(2004)$. Influence of soaking and cooking On thiamin, riboflavin and niacin contents in legumes. Food Chemistry 84: 271-277.

Ragab HI, Kijora C, Abdelalti KF, Danier J(2010). Effect of traditional Processing on the nutritive value of some legumes seeds produced in Sudan for Poultry feeding. Int. J. Poult. Sci., 9: 198-204.

Roy F, Boye JI, Simpson BK(2010). Bioactive proteins and peptides in pulse crops: Pea, chickpea and lentil. Food Research International 43: 432-442.

Sharma S, Kaur M, Goyal R, Gill BS(2011). Physical characteristics and nutritional composition of some new soybean (Glycine max (L.) Merrill) genotypes, Journal of Food Science and Technology. DOI 10.1007/s13197-011-0517- 7.

Young SM, JS Greaves(1990). Influence of variety and treatment on phytin content of wheat. Food Res., 5: 103-105 